\title{
Literasi Digital Peserta Didik Sekolah Dasar: Sebuah Studi Kepustakaan
}

\author{
*Mardiana \\ SDN 006 Sangkulirang- Dinas Pendidikan Kutim \\ email: mardianafirdaus93@gmail.com
}

\begin{tabular}{|c|c|}
\hline (A) Check for updates open $\partial_{\text {access }}$ (C) (i) & DOI: https://doi.org/10.53621/jider.v1i2.52 \\
\hline Informasi Artikel & ABSTRAK \\
\hline Riwayat Artikel: & \multirow{11}{*}{$\begin{array}{l}\text { Tujuan penelitian ini mendeskripsikan literasi digital peserta didik sekolah } \\
\text { dasar pada masa pandemi Covid-19, penelitian ini menggunakan pendekatan } \\
\text { kualitatif dengan penelitian kepustakaan atau literatur research dengan } \\
\text { langkah-langkah dalam penelitian ini dimulai dengan: } 1 \text {. Membuat kata kunci } \\
\text { "literasi digital peserta didik", "literasi digital masa Covid-19" dan "Dampak } \\
\text { Covid-19", 2. pencarian artikle melalui Google Cendekia/ google scholar, } 3 \\
\text { Data yang terkumpul di bagi pada bagian penting. Analisis artikel dan } \\
\text { disajikan datanya dan kemudian di analisa kualitatif deskriptif dengan miles } \\
\text { dan hubermen penekanannya pada penarikan kesimpulan. Hasil penelitian } \\
\text { menemukan bahwa konsep literasi digital menurut Bawden yang tersusun } \\
\text { atas empat komponen yaitu kemampuan dasar literasi peserta didik dalam } \\
\text { baca tulis, latar belakang pengetahuan informasi (tingkat intelektualitas), } \\
\text { keterampilan di bidang TIK, serta sikap dan perspektif informasi (attitudes and } \\
\text { perspective). Penekanann peserta didik dalam literasi digital sebagai } \\
\text { kemampuan memanfaatkan teknologi, memaknai dan memahami, serta } \\
\text { menilai kredibilitas informasi yang ada pada konten digital walaupun dalam } \\
\text { masa Covid-19 saat ini. }\end{array}$} \\
\hline Diterima: 28 September 2021 & \\
\hline Revisi Akhir: 30 Oktober 2021 & \\
\hline Disetujui: 31 Oktober 2021 & \\
\hline Terbit: 31 Oktober 2021 & \\
\hline Kata Kunci: & \\
\hline Litarasi digital, & \\
\hline Peserta didik, & \\
\hline Sekolah dasar, & \\
\hline Masa pandemi Covid-19 & \\
\hline & \\
\hline
\end{tabular}

\section{PENDAHULUAN}

Literasi digital saat ini merupakan aktivitas yang sudah menjadi kegiatan sehari-hari. Kemajuan teknologi informasi berbasis digital sudah dapat dirasakan oleh seluruh rakyat Indonesia, dimanapun daerahnya di negeri ini baik di kota besar sampai pula di daerah-daerah terpencil sudah dapat mengakses informasi melalui berbagai perangkat digital.

Sebagai suatu aktivitas yang sangat penting literasi digital di era pertumbuhan teknologi yang semakin maju diharapkan dapat diterapkan dengan baik, walaupun kondisi masa pandemi Covid-19 sangat sulit dalam melakukan interaksi pembelajaran dengan baik. Karena kondisi Covid-19 mengancam jiwa manusia yang menyebabkan kematian, banyak ditemukan kasus kematian akibat Virus Covid-19 (Goo et al., 2020), beragam kesamaan jenis virus yang menyerang manusia di tahun 2019 hingga sekarang (Farooq et al., 2020).

Dengan kasus Covid-19 yang menyebar menjadi ancaman kesehatan dunia saat ini, maka pemerintah Indonesia menetapkan pembelajaran jarak jauh dengan menggunakan e-learning dan media sosial bagi para guru dalam aplikasinya (Salehudin et al., 2021), banyak guru menerapak e-learning dalam pembelajaran jarak jauh (Bates \& Bates, 2005), guru mengadopsi media sosial untuk aktivitas pembelajaran pada saat Covid-19 yang mengakibatkan pembelajaran menjadi pembelajaran jarak jauh (Salehudin, 2020), memberikan dampak baru pada aktivitas pembelajaran dan khususnya pembelajaran dan literasi digital pada masa pandemi Covid-19 (Jamaludin et al., 2021).

Tumbuh dan berkembangnya teknologi memiliki pengaruh yang besar pula terhadap dunia pendidikan di Indonesia. Penggunaan berbagai sarana teknologi telah masif di pakai oleh semua kalangan untuk dapat mengakses teknologi informasi. Ketersediaan sarana dan prasarana teknologi saat ini memudahkan dalam melalukan literasi digital, termasuk di kalangan peserta didik pada semua level pendidikan di Indonesia, tidak terkecuali peserta didik sekolah dasar. 
Literasi digital dalam pendidikan di sekolah dapat diakses dengan media-media digital disekitar lingkungan sekolah seperti dengan hand phone atau smartphone, komputer PC, laptop, dan sebagainya. Ketersediaan sarana dan fasilitas ini akan memudahkan peserta didik melakukan literasi digital. Namun permasalahannya apakah semua sekolah telah menerapkan aktivitas literasi digital sebagai sebuah kurikulum sekolah dengan memanfaatkan media pembelajaran berbasis digital untuk melatih keterampilan peserta didik. Hal inilah yang menjadi hal menarik untuk diketahui dan dijabarkan sebagai pengetahuan dan bahan kajian bagi lembaga sekolah yang akan maju dengan menerapkan literasi digital.

Sehingga aktivitas literasi digital bagi peserta didik diharapkan dapat menjadi tolak ukur dan faktor-faktor kesuksesan dalam pengembangan pengetahuan dan keterampilan peserta didik sekolah dasar. Perhatikan bahwa penempatan literasi digital dalam sebuah kurikulum, dibeberapa kasus penelitian bahwa kurikulum literasi digital di lembaga pendidikan penting (Nelson et al., 2011), selain untuk kebutuhan tuntutan zaman, literasi digital juga lebih efektif bagi pembelajaran pada era pembelajaran abad 21 saat ini, karena pembelajaran menjadi lebih menarik, menyenangkan dan bervariasi bagi generasi alfa yang sudah sangat dekat dengan teknologi, sebab ada hubungannya antara literasi digital dengan kemandirian peserta didik (Akbar \& Anggaraeni, 2017).

Sebuah pertanyaan menarik yang memerlukan jawaban adalah bagaimana Implementasi literasi digital bagi peserta didik di sekolah dasar yang diharapkan mampu menambah suatu informasi yang belum diketahui oleh peserta didik dan mampu memberikan pembelajaran yang kreatif dan inovatif. Melihat hal ini bahwa literasi digital adalah sesuai tuntutan zaman dan literasi digital yang harapannya dapat menggunakan teknologi sebagai wahana pengajaran yang dilaksanakan guru dalam mencapai individu sebagai bangsa yang berkarakter atau sebagai pusat penguatan karakter, sebab pada era saat ini generasi muda (peserta didik) sudah sangat akrab dengan dunia digital serta media sosial melalui internet (Pohan \& Suparman, 2020). Secara keseluruhan literasi digital memiliki hubungan yang signifikan dengan kualitas penggunaan eresources, dengan kategori very high correlation, artinya literasi digital menjadi faktor yang sangat menentukan terhadap tingginya kualitas penggunaan e-resources (Nurjanah et al., 2017).

Beberapa penelitian sebelumnya telah menemukan beberapa bagian penting yang memiliki hubungan dengan literasi digital. Penelitian Hamdani \& PriatnaF (2020) hasil penelitiannya tentang tingkat efektifitas pembelajaran dari 8 indikator yang diteliti yaitu sekitar 66,97\%. Berdasarkan delapan indikator yang diteliti diantaranya tentang 1) Kenyamanan Pembelajaran Masa, Pandemi; 2) Kemampuan Literasi Digital Guru.

Penelitian lainnya oleh Rembulan Catra Banyu Biru et al 2020, temuan yang didapatkan bahwa keterampilan literasi digital mahasiswa dapat dikategorikan baik, bahwa untuk melakukan pembelajaran secara mandiri yang optimal dibutuhkan keterampilan menggunakan teknologi yang baik atau dikenal dengan istilah literasi digital (Biru et al., 2020).

Banyak literatur yang membahas tentang pentingnya literasi digital pada peserta didik, literasi digital siswa sekolah dasar di Den Haag (Ahsani et al., 2021), menerapkan strategi pembelajaran daring maka kemampuan literasi digital mutlak dibutuhkan para pelajar (Sudyana \& Surawati, 2021) dan seberapa besar pendidikan karakter literasi digital sebagai solusi di era COVID-19 (Yasid, 2020).

Tujuan penelitian ini untuk mendeskripsikan literasi digital peserta didik sekolah dasar di masa pandemi-19, pembelajaran harus tetap dilaksanakan dalam kondisi yang menimpa Indonesia saat ini, literasi digital menjadi sarana yang tepat untuk menjadi bagian dalam pembelajaran online saat ini. Penelitian ini membuat pertanyaan kunci yang menarik bagaimana literasi digital peserta didik sekolah dasar di masa pandemi-19?.

\section{METODE PENELITIAN}

Penelitian ini menekankan pada sebuah kajian literatur atau studi literatur. Studi literatur atau penelitian kepustakaan ialah sebuah studi yang mempelajari beragam buku rujukan dan hasil penelitian terdahulu yang relevan guna memperoleh landasan teori mengenai masalah 
yang hendak diteliti (Sugiono, 2010), penelitian literatur digunakan untuk mendeskripsikan data kualitatif menjadi lebih akurat dan tepat (Patton, 2009).

Sesuai dengan tujuan penelitian untuk mendeskripsikan literasi digital peserta didik sekolah dasar masa Covid-19. Kajian literatur menjadi kajian penting dengan membuat sebuah peta literatur (Creswell, 2013). Maka langkah-langkah dalam penelitian ini dimulai dengan 1. Membuat kata kunci "literasi digital peserta didik", "literasi digital masa Covid-19" dan "Dampak Covid-19", 2. Dilakukan melalui mesin pencari Google Cendekia/ google scholar, 3. Data yang terkumpul di bagi pada bagian penting. Data dilihat pada artikel yang di baca: 1 . Tujuan penelitian, 2. Pendahuluan, 3. Hasil dan pembahasan serta 4. Kesimpulan. Kemudian, analisis dilakukan dengan menyusunkan data dari berbagai artikel dan disajikan datanya dan kemudian di analisa kualitatif deskriptif dengan Miles \& Huberman (1992) penekanannya pada penarikan kesimpulan, sehingga memperoleh hasil yang maksimal.

\section{HASIL DAN PEMBAHASAN}

Hasil penelitian menemukan bahwa, literasi dapat diartikan secara sederhana sebagai kemampuan seseorang dalam membaca dan menulis. Kata literasi berasal dari bahasa Inggris yaitu literacy yang diartikan sebagai kemapuan baca tulis. Pembelajaran daring menjadi suatu kebiasaan proses pembelajaran baru. Ketika pandemi Covid-19 menjadi wabah yang belum ada proses penanganan dan penyelesaiannya. Hal ini mendorong kualitas pembelajaran secara tidak langsung menerapkan suatu pola belajar baru yang berbasis literasi digital (Alrianingrum et al., 2021).

Hasil temuan yang mendasar bagi peserta didik sekolah dasar bahwa ada pendekatan dan konsep yang dikembangkan oleh seorang pakar Bawden (2008) yang menemukan bahwa pembentukan literasi digital adalah dengan konsepsi yang menghubungkan literasi digital dengan literasi komputer dan literasi informasi. Apabila diuraikan lebih mendetal, konsep literasi digital menurut Bawden tersusun atas empat komponen yaitu kemampuan dasar literasi (baca tulis), latar belakang pengetahuan informasi (tingkat intelektualitas), keterampilan di bidang TIK, serta sikap dan perspektif informasi (attitudes and perspective).

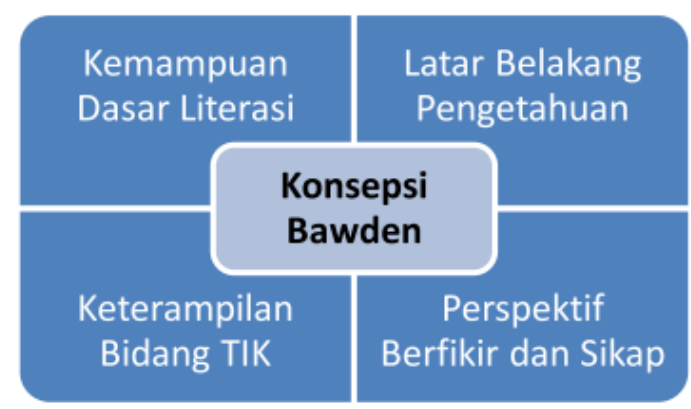

Gambar 1: Literasi Digital dalam konsep Bawden (Bawden, D., 2008, Origins and concepts of digital literacy, in: Digital Literacies: Concepts, Policies and Practices, Peter Lang Publishing, New York)

Dari temuan literasi tersebut bahwa: pertama: Kemampuan dasar literasi mencakup kemampuan untuk membaca, menulis, memahami simbol, dan perhitungan angka; kedua: Latar belakang pengetahuan informasi merupakan kemampuan menggunakan pengetahuan yang telah dimiliki, untuk menelusuri informasi baru guna memperkaya pengetahuan yang telah dimaki; Ketiga: Keterampilan bidang TIK merupakan menciptakan/menyusun konten digital. Keterampilan ini merupakan kompetensi utama dalam bidang literasi digital, dan melibatkan kemampuan merakit informasi atau pengetahuan; dan ke empat: Sikap dan perspektif pengguna informasi merupakan perilaku yang terkait dengan tata cara penggunaan informasi digital, dan bagaimana mengkomunikasikan suatu konten yang mengandung informasi dari sumber lain.

Peserta didik sekolah dasar dalam pembelajaran berliterasi digital dapat berjalan dengan efektif, efisien dan menarik anak apabila seorang perancang program memahami siapa atau 
individu yang akan dihadapinya, perilaku yang kita harapkan mampu dikerjakan dan dipelajari anak, materi yang akan disampaikan, target yang akan dicapai oleh anak, program pembelajaran literasi digital memiliki tahapan yang jelas yakni pembuatan tujuan jangka pendek dan panjang. Literasi digital sebagai kemampuan memanfaatkan teknologi, memaknai dan memahami, serta menilai kredibilitas informasi yang ada pada konten digital.

Dalam pelaksanaan gerakan literasi sekolah terdapat hambatan yang terjadi. Hambatan utama yaitu pada siswa yang kelas rendah. Hal tersebut karena rata-rata pada siswa kelas rendah masih minim akan membacanya. Solusi pada hambatan tersebut adalah guru harus terlebih dahulu mengenalkan huruf atau abjad sebelum mengajarkan membaca kepada siswa.

Hambatan lain yang terjadi adalah rasa malas yang terjadi pada siswa maupun guru terkadang menjadi sebuah hambatan dalam gerakan literasi sekolah. Rasa malas tersebut di karenakan tidak semua siswa dan guru mempunyai latar belakang yang suka membaca. Ada hal lain yang menyebabkan hambatan dalam pembelajaran yaitu peserta kurang fokus terhadap penjelasan guru sehingga peserta didik belum bisa mengikuti pembelajaran sepenuhnya.

Layanan literasi digital dianggap cukup efektif untuk meningkatkan minat baca siswa di masa pandemi Covid-19. Hal itu bisa dilihat dari mayoritas siswa lebih senang membaca melalui layanan literasi digital karena banyak informasi yang bisa diperoleh dengan mudah (Wulandari \& Sholeh, 2021).

Gilster dalam A'Yuni (2015) menjelaskan bahwa konsep literasi bukan hanya mengenai kemampuan untuk membaca saja melainkan membaca dengan makna dan mengerti. Literasi digital mencakup penguasaan ide-ide, bukan penekanan tombol (A'yuni, 2015). Literasi digital menjadi budaya maka dapat memberikan dampak positif bagi kehidupan sosial serta budaya masyarakat. Membangun budaya literasi digital sangat memerlukan keterlibatan antara semua pihak dan keberhasilan literasi digital merupakan salah satu capaian indikator pada bidang pendidikan.

Bagi peserta didik sekolah dasar untuk kegiatan literasi digital pada masa pandemic Covid19 di SD Laboratorium Percontohan UPI Serang berjalan dengan cukup baik dan lancar meski mengalami beberapa kesulitan (Andarini \& Salim, 2021) dan melaksanakan literasi digital dengan memperhatikan kompetensi inti yang perlu dimiliki seseorang sehingga dapat dikatakan berliterasi digital, karakteristik kompetensi terdapat empat bagian penting adalah pertama: pencarian informasi di internet dengan menggunakan search engine, serta melakukan berbagai aktivitas di dalamnya, kedua: Pengetahuan tentang hypertext dan hyperlink beserta cara kerjanya, Pengetahuan tentang perbedaan antara membaca buku teks dengan melakukan browsing via internet. Pengetahuan tentang cara kerja web meliputi pengetahuan tentang bandwidth, http, html, dan url, serta Kemampuan memahami karakteristik halaman web. Ketiga: Kemampuan mengevaluasi suatu alamat web dengan cara memahami macam-macam domain untuk setiap lembaga ataupun negara tertentu, Kemampuan menganalisa suatu halaman web, serta Pengetahuan tentang FAQ dalam suatu newsgroup/grup diskusi dan ke empat: kemampuan untuk menyusun pengetahuan, membangun suatu kumpulan informasi yang diperoleh dari berbagai sumber dengan kemampuan untuk mengumpulkan dan mengevaluasi fakta dan opini dengan baik serta tanpa prasangka.

Literasi digital merupakan transformasi dari pengajaran secara manual dengan mempergunakan buku paket atau buku teks, dan merupakan dunia baru dalam sistem pembelajaran saat ini, sehingga bagi guru perlu meningkatkan potensi dalam penggunaan teknologi digital agar tidak gagap teknologi saat mengakses proses pembelajaran melalui jaringan internet (Pohan \& Suparman, 2020). Dengan literasi digital dalam dunia pendidikan dapat dijadikan sebagai media untuk memudahkan proses pembelajaran. Pengaruh literasi digital dalam pembelajaran dapat merespons intelektual siswa untuk memunculkan pemikiran humanisme digital yang artinya siswa dapat berpikir dan menambah pengetahuan dengan adanya pemanfaatan literasi digital.

Menurut Paul Gilster (1997: 18) dalam Dewa Kadek Sudyana, yaitu; pencarian internet, panduan arah hypertext, evaluasi konten informasi dan penyusunan pengetahuan. Pencarian di 
Internet (Internet Searching) adalah Kompetensi sebagai suatu kemampuan seseorang untuk menggunakan internet dan melakukan berbagai aktivitas di dalamnya. Kompetensi ini mencakup beberapa komponen yakni kemampuan untuk melakukan pencarian informasi di internet dengan menggunakan search engine, serta melakukan berbagai aktivitas di dalamnya (Sudyana \& Surawati, 2021, 3).

Kriteria literasi digital menurut Techataweewan \& Prasertsin, 2018 dalam Rembulan Catra Banyu Biru 2020, Faktor Keterampilan operasi terdiri dari tiga indikator: kognisi, penemuan, dan presentasi. Indikator pertama adalah kognisi yang mengacu pada pengetahuan dan pemahaman tentang TIK dan media digital. Kemampuan untuk mengintegrasikan dan mengaplikasikan TIK dan media digital untuk menemukan pekerjaan, menciptakan pengetahuan, atau melakukan inovasi. Menyajikan konten digital dalam berbagai format seperti pemilihan format yang sesuai untuk audiens target yang memberi dan untuk menerima umpan balik yang efektif (Biru et al., 2020).

Keterampilan menggunakan teknologi digital mempermudah seseorang untuk melakukan pembelajaran secara mandiri (Siriwongs, 2015), Literasi digital adalah pengetahuan dan kecakapan untuk menggunakan media digital, alat-alat komunikasi, atau jaringan dalam menemukan, mengevaluasi, menggunakan, membuat informasi, dan memanfaatkannya secara sehat, bijak, cerdas, cermat, tepat, dan patuh hukum dalam rangka membina komunikasi dan interaksi dalam kehidupan sehari-hari (Hanik, 2020). Ada tiga komponen literasi digital yaitu suatu kompetensi dalam memanfaatan teknologi, memaknai serta menilai menilai sumber literasi berbasis digital, meneliti serta mengkomunikasikan informasi dan pengentahuan tentang hasil literasi digital dengan penuh rasa bertanggung jawab. Secara konsep, hal yang paling mudah untuk dijadikan literasi pendidikan adalah melalui media literasi digital (Ahsani et al., 2021).

\section{KESIMPULAN}

Literasi digital lebih efektif pada pembelajaran era pembelajaran abad 21 saat ini, karena pembelajaran menjadi lebih menarik, menyenangkan dan bervariasi bagi generasi alfa yang sudah sangat dekat dengan teknologi. Literasi digital peserta didik sekolah dasarmemperhatikan dan menggunakan konsep literasi digital, menurut Bawden yang tersusun atas empat komponen yaitu kemampuan dasar literasi peserta didik dalam baca tulis, latar belakang pengetahuan informasi (tingkat intelektualitas), keterampilan di bidang TIK, serta sikap dan perspektif informasi (attitudes and perspective). Penekanan peserta didik dalam literasi digital sebagai kemampuan memanfaatkan teknologi, memaknai dan memahami, serta menilai kredibilitas informasi yang ada pada konten digital walaupun dalam masa Covid-19 saat ini.

\section{DAFTAR PUSTAKA}

A'yuni, Q. Q. (2015). Literasi Digital Remaja Di Kota Surabaya. Jurnal Fakultas Ilmu Sosial Dan Ilmu Politik Universitas Airlangga Surabaya, 4(2), 1-15. http://journal.unair.ac.id/literasidigital-remaja-di-kota-surabaya-article-9195-media-136-category-8.html

Ahsani, E. L. F., Romadhoni, N. W., Layyiatussyifa, E. L., Ningsih, W. N. A., Lusiana, P., \& Roichanah, N. N. (2021). Penguatan literasi digital dalam pembelajaran di Sekolah Dasar Indonesia Den Haag. Elementary School, 8(2), 228-236.

Akbar, M. F., \& Anggaraeni, F. D. (2017). Technology in Education: Digital Literation and SelfDirected Learning in Students Students. Jurnal Indigenous, 2(1), 28-38.

Alrianingrum, S., Artono, Aji, R. N. B., \& Hermawan, E. S. (2021). Efektivitas Pembelajaran Daring Untuk Menumbuhkan Literasi Digital Masa Darurat Covid-19. Researchgate.Net, April.

Andarini, F. A., \& Salim, H. (2021). Implementasi Literasi Digital Pada Pembelajaran Sekolah Dasar Saat Pandemi. Didaktika, 1(1), 181-189.

Bates, A. W., \& Bates, T. (2005). Technology, e-learning and distance education. Psychology Press.

Biru, R. C. B., Saepudin, A., \& Sardin. (2020). Analisis Literasi Digital Terhadap Pembelajaran Mandiri Di Masa Pandemi Covid-19. Indonesian Journal Of Adult and Community Education, 
2(2), 61-69. https:/ / ejournal.upi.edu/index.php/IJACE/article/view/30882

Creswell, J. W. (2013). Research Design Qualitative Quantitative And Mixed Method Approaches. SagePublications.

Farooq, H. Z., Davies, E., Ahmad, S., Machin, N., Hesketh, L., Guiver, M., \& Turner, A. J. (2020). Middle East Respiratory Syndrome Coronavirus (MERS-CoV) - surveillance and testing in North England from 2012 to 2019. International Journal of Infectious Diseases, 93(August 2018), 237-244. https:/ / doi.org/10.1016/j.ijid.2020.01.043

Goo, J., Jeong, Y., Park, Y. S., Yang, E., Jung, D. I., Rho, S., Park, U., Sung, H., Park, P. G., Choi, J. ah, Seo, S. H., Cho, N. H., Lee, H., Lee, J. M., Kim, J. O., \& Song, M. (2020). Characterization of novel monoclonal antibodies against MERS-coronavirus spike protein. Virus Research, 278(October 2019), 197863. https:/ / doi.org/10.1016/j.virusres.2020.197863

Hamdani, A. R., \& Priatna, A. (2020). Efektifitas Implementasi Pembelajaran Daring (Full Online) Dimasa Pandemi Covid- 19 Pada Jenjang Sekolah Dasar Di Kabupaten Subang. Didaktik: Jurnal Ilmiah PGSD STKIP Subang, 6(1), 1-9. https:/ / doi.org/10.36989/ didaktik.v6i1.120

Hanik, E. U. (2020). Self Directed Learning Berbasis Literasi Digital Pada Masa Pandemi Covid19 Di Madrasah Ibtidaiyah. Elementary Islamic Teacher Journal, 8(1), 183-208.

Jamaludin, G. M., Araniri, N., \& Nahriyah, S. (2021). Meningkatkan literasi digital bagi guru dalam menghadapi pembelajaran daring di masa Covid 19. BERNAS: Jurnal Pengabdian Kepada Masyarakat, 2(3), 714-718. https:/ / doi.org/10.31949/jb.v2i3.1193

Miles, M. B., \& Huberman, A. M. (1992). Analisis Data Kualitatif. UI Press.

Nelson, K., Courier, M., \& Joseph, G. (2011). Teaching Tip: An Investigation of Digital Literacy Needs of Students. Journal of Information Systems Education, 22(2), 95-109.

Nurjanah, E., Rusmana, A., \& Yanto, A. (2017). Hubungan Literasi Digital dengan Kualitas Penggunaan E-Resources. Lentera Pustaka: Jurnal Kajian Ilmu Perpustakaan, Informasi Dan Kearsipan, 3(2), 117. https:/ / doi.org/10.14710/lenpust.v3i2.16737

Patton, M. Q. (2009). Metode Evaluasi Kualitatif. Pustaka Pelajar.

Pohan, S. S., \& Suparman. (2020). Perspektif Literasi Digital Bagi Guru Sekolah Dasar. Jurnal IlmuIlmu Sejarah, Sosial, Budaya Dan Kependidikan, 7(1), 164-178.

Salehudin, M. (2020). Dampak Covid-19: Guru Mengadopsi Media Sosial Sebagai E-Learning Pada Pembelajaran Jarak Jauh. Jurnal MUDARRISUNA, 10(1), 1-16.

Salehudin, M., Zulherman, Arifin, A., \& Napitupulu, D. (2021). Extending Indonesia Government Policy for E-Learning and Social Media Usage. Pegem Journal of Education and Instruction, 11(2), 14-26. https:/ / doi.org/10.14527/ pegegog.2021.00

Siriwongs, P. (2015). Developing Students' Learning Ability by Dint of Self-Directed Learning. Procedia - Social and Behavioral Sciences, 197(February), 2074-2079. https:// doi.org/10.1016/j.sbspro.2015.07.577

Sudyana, D. K., \& Surawati, N. M. (2021). Analisis penerapan literasi digital dalam menciptakan kemandirian belajar siswa hindu di masa pandemi covid 19. Widyanatya, 3, 1-5.

Sugiono. (2010). Metode Penelitian Pendidikan; Pendekatan Kuantitatif, Kualitatif dan RED (cetakan ke). Alfabeta, CV.

Wulandari, D. R., \& Sholeh, M. (2021). Efektivitas Layanan Literasi Digital Untuk Meningkatkan Minat Baca Siswa Di Masa Pandemi Covid-19. Jurnal Inspirasi Manajemen Pendidikan, 9(2), 327-335.

Yasid, A. (2020). Strategi Pembelajaran Berbasis Karakter Literasi Digital Menghadapi Pandemi Covid-19. Prosiding Seminar Nasional Pendidikan Biplogi., September, 52-56. http:/ / researchreport.umm.ac.id/index.php/psnpb/article/view/3647 